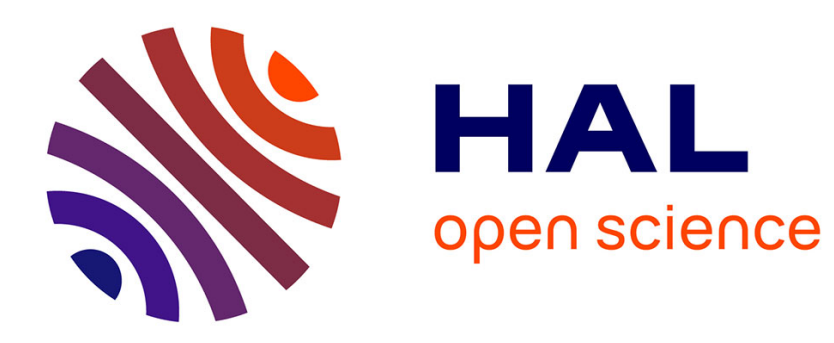

\title{
A schematic view of government as regulator and insurer of the financial system
}

\author{
Henri-Paul Rousseau
}

\section{To cite this version:}

Henri-Paul Rousseau. A schematic view of government as regulator and insurer of the financial system. 2019. halshs-01993612

\section{HAL Id: halshs-01993612 \\ https://shs.hal.science/halshs-01993612}

Preprint submitted on 25 Jan 2019

HAL is a multi-disciplinary open access archive for the deposit and dissemination of scientific research documents, whether they are published or not. The documents may come from teaching and research institutions in France or abroad, or from public or private research centers.
L'archive ouverte pluridisciplinaire HAL, est destinée au dépôt et à la diffusion de documents scientifiques de niveau recherche, publiés ou non, émanant des établissements d'enseignement et de recherche français ou étrangers, des laboratoires publics ou privés. 


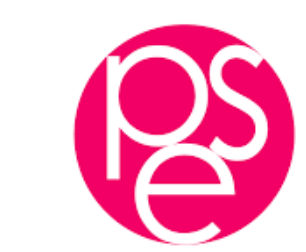

PARISSCHOOLOFECONOMICS
ECOLED'ECONOMIE DE PARIS

WORKING PAPER N 2019 - 07

\section{A schematic view of government as regulator and insurer of the financial system}

Henri-Paul Rousseau

JEL Codes:

Keywords :
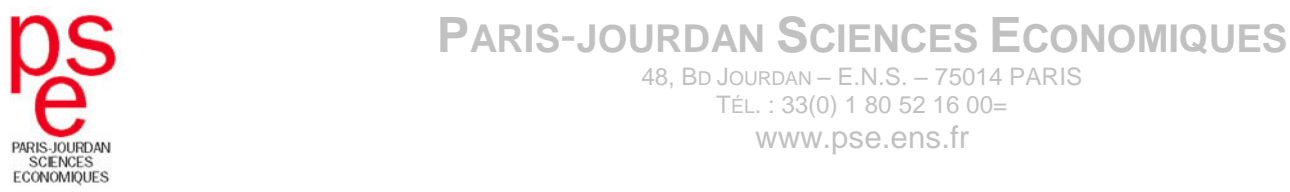


\title{
A SCHEMATIC VIEW OF GOVERNMENT AS REGULATOR AND INSURER OF THE FINANCIAL SYSTEM
}

\begin{abstract}
The purpose of this paper is to present a schematic of the interactions between the government as the REGULATOR of financial institutions and the government as the INSURER of financial institutions while taking into account the long-term feedback relationships between the size and the scope of the financial sector and the level of public debt resulting from financial crises over time. The analysis concludes that at certain high level of public debt and size of the expected support of the financial sector by the government, the regulator and /or the central bank may have to "stabilize" the situation, but there may be cases where the support becomes socially "unacceptable."
\end{abstract}

January 2019

Henri-Paul Rousseau

Visiting Professor

Paris School of Economics

* I want to thank Messrs. Richard Pan (Power Corporation of Canada), Matt Gertken and Marko Papic (BCA Research) for their help, comments and suggestions.

Questions and comments are welcome at henri-paul.rousseau@psemail.eu 


\section{Introduction}

The Global Financial Crisis has revealed the complexity of the numerous relationships between the financial sector and the State. Indeed, as well argued by Alessandri and Haldane (2009), governments have acted as liquidity insurer (lender of last resort), as deposit and capital insurer, and as regulator. Governments (and their central banks) also took action to get the world economy out of the recession at the expense of their own revenues and balance sheets, which were strongly negatively impacted by the crisis. Moreover, in many countries, a large part of the government debt ended up in the hands of the financial sector, which in many cases was helped by the central bank if not by the government itself. This "diabolical loop," a phrase coined by Brunnermeier et al (2016), is the topic of many debates and studies.

The purpose of this paper is to present a schematic view of these interactions between the government as the REGULATOR of financial institutions and the government as the ultimate deposit and capital INSURER, while taking into account the long-term feedback relationship between the size and the scope of the financial sector and the level of the public debt. These relationships have been well documented by Schularick, Taylor and Jordà (2012a, 2013, 2012b). The new schematic tool is then used to show how the long-term evolution of these interactions may create different equilibria.

In the first section, I introduce the key definitions, concepts and measures.

In the second section, I consider different regulatory regimes and their potential impacts on the government as insurer if a financial crisis arises. In the case of a country with a relatively small level of public debt and a relatively small financial sector, the "music continues to play" since the government can afford to cope with the crisis. But in the case of a country with a high level of public debt and a large financial sector, the government has no other choice than to change the regulatory rules to accommodate the situation: "something's got to give" ... unless the central bank "stabilizes" the situation by monetizing the public debt. But it may happen that certain levels of public debt and certain sizes of the government's expected support of the financial sector become not only "unstable" but also politically "unacceptable." A "new social contract" is needed in order to stabilize the system. The final section offers some concluding remarks.

\section{Definitions, Concepts and Measures: Building the Schematic View}

A country's financial regulator oversees the activities of financial institutions by determining:

i) What these institutions can do: the scope of the financial services they can or cannot offer (the Y1 axis in Mapping I and Mapping II),

ii) The conditions under which they operate: the regulations of these institutions (Mapping I), and

iii) How they can do it: products and markets regulations (Mapping II). 
All these concepts are illustrated in Graph A.

The time horizon in this paper is important. Every point on any one of these mappings or axes should be viewed not as a one-year time period but more as a period corresponding to a specific regulatory regime. For example, the years of the Classical Gold Standard from 1870 until 1914 would correspond to a point in any axis on graph $A$.

\section{Mapping I: The Financial Institutions Regulations Space The Scope of the Financial Sector: the Y1 axis}

The scope of the financial sector is the legal regime that determines which activities banks and other financial institutions are legally authorized to provide. While the scope of the financial sector is greatly influenced by the choices made by the regulator, this scope is also impacted by other policies and other economic and technological trends.

Historically, various philosophies have underpinned these legal regimes, ranging from the most conservative (commercial banks being restricted to one single activity: lending; which in turn was limited by the amount of their gold reserves on the balance sheet) to the most liberal (commercial banks institutions were authorized to provide trust, brokerage and insurance services as they competed with pensions funds, assets managers, insurance corporations and the shadow banking sector, all offering a very large number of sophisticated, sometimes opaque and unregulated products).

Markham (2000) traces the history of the growth and regulation of the banking industry in the United Sates and Ersel (2011) offers a comprehensive overview of the evolution of Basel I and Basel II, while Santos (2000) reviews the theoretical literature on bank capital and analyses some of the approaches to redesign the 1988 Basel Accord on capital. One of the most comprehensive overviews of the global regulatory reform proposals since the 2008-09 financial crisis is available at The Global Financial Markets Association (2013). The latest version of these side-by-side comparisons and timelines by topic areas and for the US, EU, UK and many other countries is as of 31 March 2013.

Over the years, the trend in the expansion of the scope of the financial system is quite clear. Schularick and Taylor (2012b) offer a well-documented survey of the evolution, not only in the US, but also in many countries. Their data set covers 14 developed countries from 1870 to 2008. Based on this research, Jordà, Schularick and Taylor (2013) distinguish four areas of financial development.

"The first era runs from 1870 to the outbreak of the World War I in 1914. This is the era of classical gold standard, with fixed exchange rates and minimal government involvement in the economy in terms of monetary and fiscal policies. The establishment of the Federal Reserve in 1913 coincides with the end of a laisserfaire epoch. The second era [...] is delineated by the two world wars. After World War I attempts were made to reconstitute the classical gold standard, but its credibility was much weakened and governments started to play a bigger role in 
economic affairs. The Great Depression of the 1930s would become the watershed for economic policymaking in the 20th century. The third period [...] is the postwar reconstruction period between 1945 and 1970. After World War II, central banks and governments played a central role in stabilizing the economy and regulating the financial sector. Capital controls provided policy autonomy despite fixed exchange rates under the Bretton Woods system. The last era runs from 1970 until today. It is marked by active monetary policies, rapid growth of the financial sector and growing financial globalization". (Jordà, Schularick and Taylor 2013)

That period is also the period of the great deregulation, as will be discussed later.

Schularick and Taylor (2012b) summarize these trends as follows: "Our ancestors lived in an Age of Money, where credit was closely tied to money, and formal analysis could use the latter as a proxy for the former. Today we live in a different world, an Age of Credit, where financial innovation and regulatory ease broke that link setting in motion an unprecedented expansion of the role of credit in the macro economy".

We must add that the recent re-regulation of the financial sector by the G20 under the leadership of the Global Stability Board and the BIS clearly marks the beginning of a fifth era where the scope of the financial sector will be again more restrained by regulators. Indeed, in the US, the Volcker Rule limiting banks' capacities to invest for their own account in private equity and hedge funds and, in the UK, the ring-fencing rules requiring largest banks to separate core retail banking services from investment and international activities of commercial banking are clear examples of regulators trying to limit the scope of their domestic financial sector.

The scope of a country's financial sector is not only determined by regulations but also other public policies. Indeed, the international scope of the financial sector is dependent on the degree of openness of the financial sector as allowed by policies on international trade and capital flow. Moreover, technologies play a crucial role in the expansion of the off-balance sheet activities pursued by financial institutions. Credit derivatives, passive asset management and ETF's would not be as important as they are today without the technologies supporting them.

Finally, to some degree, the fiscal regime of a country does influence the flow of transactions that financial institutions execute as well as the multiple interconnections they entertain locally and globally.

The Mapping I in Graph A refers to the $\mathrm{Y} 1$ axis as the scope of a financial sector. Along the Y1 axis, the historical period corresponding to the Classical Gold Standard, where commercial banks' lending capacity was constrained by a specific reserve ratio, would be very close to the origin of the $\mathrm{Y} 1$ axis. On the contrary, the period just before the Global Financial Crisis, where universal global institutions could target a universal scope, would correspond to the high end of the $\mathrm{Y} 1$ axis. This is why a good measure of the scope of the financial sector is the sum of wholesale funding plus foreign assets plus off-balance sheet assets of the financial institutions of a given country all expressed as a percent of their total assets. 
From a regulatory perspective, there must be a very close relationship between three types of regulations:

- Those defining the scope of the financial institutions' activities (Y axis);

- Those constraining the balance sheet of the financial institutions (Mapping I); and

- The regulations governing the design of financial products and the markets where they are exchanged (the financial multiplier in Mapping II).

The regulatory choices directly impacting the financial institutions (Mapping I) are:

- The definition of systemic risk and systemically important institutions;

- The crisis management and recovery and the resolution planning including bail-in provisions;

- The total leverage limits and the capital requirements regime, including compulsory stress tests;

- The liquidity regulations;

- The accounting standards; and

- The compensation regulation.

The deposit insurance programs should also be viewed as part of these regulations that directly impact banks and other depository financial institutions.

One could be tempted to add to this list all the other regulations concerning derivatives, securitization, hedge funds, commodities, short sales, etc. But, some of these regulations, like the prohibition of interstate banking in the US between 1956 and 1994, the Volcker Rule in the US, or the Ring-Fencing regulations in the UK, are more related to the scope of the financial institutions ( $\mathrm{Y} 1$ axis) while others like those governing securitization and derivatives are more designed for products and markets. This last category will be considered in Mapping II.

The main purpose of these prudential regulations is to reduce the likelihood of financial crises as well as the size of the support that the government would have to offer if a crisis occurred. As such, the chosen regulations will determine the slope and the shape of the relationship between the scope of the financial sector (Y1) and the expected value of the size of the government support needed in case of a financial crisis (X1) as illustrated in Mapping 1 of Graph A.

History teaches us that there is a clear positive, albeit complex, relationship between the scope of the financial sector and the expected value of the government support to this sector during a financial crisis. We call this relationship in Mapping I REGULATORY LEVERAGE. Certainly Mapping I suggests a positive relationship between $\mathrm{Y} 1$ and $\mathrm{X} 1$, but it is a non-linear one as the costs to the government as insurer have been much larger when the scope of the financial sector was greater. The recent financial crisis is case in point here.

The historical experience also illustrates that the position and the "slope" of this relationship is directly influenced by the degree of conservatism in the regulations imposed on the institutions. A more conservative approach demanding more capital and more liquidity for any given level of assets will call for a steeper relationship 
while a less conservative approach will produce a higher regulatory leverage and a flatter relationship. Thus, for a given level of scope, a point on the Y1 axis, a more conservative capital regime will be associated with a lower expected value of the government support in case of financial crisis, $\mathrm{X} 1$.

The degree of conservatism of the regulations is not the only variable to consider. The actual design of government policies is also important, as illustrated by the moral hazard problem associated with the introduction of government guarantees. As Allen, Carletti, Goldstein and Leonello (2015) explain: "On the one hand, the government can reduce the likelihood of a banking crisis by increasing the sizes of the guarantees. On the other hand, larger guarantees induce a larger disbursement for the government [...] Different guarantees schemes can differ significantly in terms of their effectiveness in preventing instability in the banking sector, the distortions that they introduce in banks' risk choices and the costs for the government providing them."

The expected value of Government support in case of a financial crisis: The $X 1$ axis

Government support, once a financial crisis arises, includes all types of measures by which governments act as a de facto liability and a capital insurer: they include capital injections, acquisitions of impaired assets, guarantees on debt instruments or deposits and subsidies to the domestic financial sector, all expressed as a percent of the domestic GDP.

They do not include, however, all liquidity support that the central bank may provide to the financial sector, such as money creation or collateral swap. (More on this later.)

That proposed measure of government support to the financial sector is consistent with most previous studies on the costs of governmental interventions during financial crises. Stolz and Wedow (2011), Laeven and Valencia (2013), the ECB (2015), and Millaruelo and del Rio (2017) have used a similar measurement methodology. For example, in 2015, it was estimated that "over the period 20082014 , accumulated gross financial sector assistance amounted to $8 \%$ of GDP of the European countries, of which $3.3 \%$ has been recovered (ECB 2015). For the US, the initial cost of the government support to the financial sector amounted to $5 \%$ of GDP but was totally recovered by 2013 (IMF 2015)."

These studies, as well as the one by Blix Grimaldi et al (2016), distinguish between three different types of costs:

a) The expected value of the government support to the financial sector during a financial crisis,

b) The actual value of this support taking into account subsequent recoveries from the financial sector, and

c) The indirect fiscal cost due to the loss in revenues and the increase in expenditures which follow the recession provoked by the financial crisis as it has been well documented by Jordà, Schularick and Taylor (2012a, 2013, 2012b). 
This last type of costs (c) is not included here in the direct measurement of government support, but it will be taken into account as part of the long-term relationship between the size of the financial sector and the size of the public debt in Mapping III.

In the same way as the Financial Stability Board and the Bank for International Settlements assess vulnerabilities in the global financial system, most domestic regulators and central bankers assess the level of systemic risk in their domestic financial sector. "Identifying, measuring, and reducing systemic risk is an important part of the task of macro prudential authorities and central banks of safeguarding stability," according to Deghi, Weiz and Zochowski (2018). This is why at each level of the scope of the financial sector, the regulators must choose to be more or less conservative on any or all aspects of their regulations.

\section{Mapping II: The Financial Products and Market Regulation Space The Financial Multiplier}

The regulator has to determine for each level of the targeted scope how financial institutions must operate by designing both products and markets regulations. These regulations cover all security and stock markets, product securitization and derivatives and any other rule that impact the size of the financial sector like mortgage design regulations, housing policies, bankruptcy laws, etc. For example, if securitization rules require a very small percentage of asset retention by the institutions securitizing their assets to third parties, smaller than one would expect, everything else being equal, then the size of the financial sector will be bigger than otherwise. Another example can be found in housing policies: a policy requiring a larger down payment for residential mortgages will be illustrated by a positive but steeper relationship between the scope and the size of the financial sector than one with a small down payment requirement.

This relationship is called the FINANCIAL AMPLIFIER as it expresses the many ingredients of the legal and regulatory framework that determine, for a given scope, the size of the financial sector as a percent of GDP.

A recent survey by Gertler and Gilchrist (2018) "on the theoretical and empirical research aimed at identifying how the financial crisis of 2008 emerged and was transmitted to the real sector" is very relevant here. Indeed, after explaining the role of the external finance premium, the financial accelerator and leverage of the nonfinancial sector, their conclusion is quite clear: "Increased securitization of mortgages permitted greater separation of the origination function of mortgages lending from lending role. As a result, lightly regulated shadow banks began to displace commercial banks as the primary founders of mortgage related securities [...] Other types of shadow banks, including asset-backed issuers and finance companies, similarly operated with high leverage." Moreover, the importance of product deregulation is well-documented: "a general relaxation of lending standards help fuel the increase in the quantity of mortgages and reduce the quality (Gertler and Gilchrist 2018)." 
All this is quite consistent with the view that the scope is very important in determining the size of the financial sector: the very rapid explosion of the financial sector after 1970 had been the result of deregulation of the scope that occurred in many countries between 1970 and 1999. The slope of the relationship between the scope and the size of the financial sector had become much flatter over that period. Regulation $Q$ on fixed interest rates was abandoned in 1986, the prohibition on interstate branching was relaxed in 1994 and the Glass-Steagal Act forbidding investment banks to engage into commercial banking activities was eliminated in 1999. After the end of the Bretton Woods system, credit began to explode and crises returned. "In 1975, the ratio of financial assets to GDP was $150 \%$ in the United States; by 2008 it has reached 350\%. In the United Kingdom, the financial sector's balance sheet reached a nadir of $34 \%$ of GDP in 1964; by 2007 this ratio had climbed to 500\%." (Jordà, Schularick and Taylor 2013) For the 14 countries of their sample, the ratio of bank loans to GDP almost doubled since the 1970s.

\section{The Size of the Financial Sector: The X2 axis}

There exist different approaches to the measurement of the size of the financial sector over time and across countries but there exists a pretty large consensus on the historical trends. Both national regulators and the Financial Stability Board have made multiple efforts to define, capture and measure the size of the regulated and the non-regulated financial system. In its latest report on "Global Shadow Banking Monitoring" (FSB 2018) the FSB estimated that Total Financial Assets were at $\$ 340$ trn at the end of 2016 of which $\$ 160$ trn were from Non-Bank Financial Intermediaries such as pension funds, insurance corporations, financial auxiliaries and the like, including the assets of captive financial institutions and money lenders. FSB established at $\$ 45$ trn the size of the "Shadow Banking" sector in this total of $\$ 160$ trn, which represent over $80 \%$ of global GDP.

This is totally consistent with other estimations like the one by Antill, Hou and Sarkar (2014).

The many different definitions and measurements of the size of the financial sector of a given country are likely to be closely correlated but, for the purpose of this paper, $\mathrm{X} 2$ is defined as the ratio of total domestic loans to households and corporations (excluding lending within the financial system) by banks which are defined broadly as monetary institutions. These are savings banks, postal banks, credit unions, mortgage associations, and building societies. Indeed the total loans of the financial sector to the private sector, net of the financing within the financial sector, are a good measure of the liabilities of the non-financial sector. When expressed as a percent of GDP it is also a measure of the "leverage of the private sector" of the economy.

This is the measurement used by Schularick and Taylor (2012b) and Schularick (2012a) in their studies establishing a strong empirical relationship between the size of the financial sector and the size of the public debt over a long period of time. 
Mapping III: Private Debt and Public Debt

The Public Debt DNA

In theory, there is no obvious positive relationship between the size of the financial sector and the size of the public debt. One can even imagine a negative relationship as a growing financial sector should be associated with a growing economy and thus growing taxable private expenditures and incomes allowing for, everything else being equal, larger government revenues and thus a smaller public debt! Over the cycles, recessions may cause the relationship between private debt and the size of the financial sector to be temporarily positive or negative. In the long run, however, a natural steady state growing economy should not be correlated to the size of the financial sector and the size of the public debt. But history has been quite different than a natural steady state and recent empirical studies have shown the impact of the size of the financial sector on the likelihood of financial crisis (Schularick and Taylor, 2012b) and on the size of the public debt over time (Schularick 2012a).

In fact, for a very long period of economic history, wars were the most likely, if not the unique, cause of high levels of public debt. But there now exists strong empirical evidence that, during the last 150 years, while wars were still very important, after World War II, the cumulative impact of financial crises has become a key factor to explain the growth of public debt in developed countries. Moreover, there is also empirical evidence that this cumulative impact of the financial sector on the public debt has been amplified by the size of the domestic financial sector (Schularick 2012a).

The logic behind these findings rests on the fact that, during financial crises, large financial sectors which are associated with more leveraged economies amplify the recession and have a prolonged negative impact on taxable incomes and expenditures of businesses and consumers which government revenues depend on. Schularick (2012a) supports that finding: "Looking at the entire period 1870-2010, public-debt ratios for the 14 countries under study increased by about $13 \%$ in the years following financial crisis with high statistical evidence [...] Before the Second World War, the increase is very small (3\%), and statistically not significant. The real story is that, after the Second World War, financial crisis have typically triggered a massive deterioration in the public-debt ratios of more than $30 \%$." The effects are particularly pronounced when crises occur in large financial sectors (Schularick and Taylor 2012b). "In post 1975 financial crises, public-debt levels jump by nearly $50 \%$ relative to a previous country's trend when the financial sector was large relative to the real economy." (Schularick 2012a) We call that long-term relationship between the size of the financial sector and the public debt the "Public Debt DNA."

Mapping III illustrates this positive historical relationship between the size of the financial sector, as measured by the total private credit as a percent of GDP, and the size of the public debt, also expressed as a percent of GDP. The mapped relationship shows that an increase of $1 \%$ (of GDP) will have more than a $1 \%$ impact on the public debt as a percent of GDP. 
Mapping IV: The Public Policy Choice Space

The Government Financial Support Capacity Frontier

For the purpose of this paper, the total liabilities of the government are composed of the total public debt, a balance sheet item, and the Expected Value of Government Financial Support in a financial crisis situation, which includes both recognized on balance sheet liabilities, like a government deposit insurance program, and unrecognized liabilities, off balance sheet items, like capital injections, guarantees and other types of financial support.

The total of these two categories of liabilities expressed as a percent of GDP can be viewed as the Government Financial Support Capacity Frontier. If the Expected Value of Government Financial Support in case of Financial Crisis were totally comparable to the value of Government Public Debt, then the Government Financial Capacity Frontier would be illustrated as a strait negative 45 degree line between Y2 and $\mathrm{X} 1$ in Mapping IV and that for each level of total resources expressed as a percent of GDP.

But the Expected Value of Government Support is an uncertain number. After all, it is determined by the probabilities of the occurrence of a financial crisis and the cost of supporting the financial sector in the event that such systemic risk materialises. For example, during the 2008 financial crisis, the initial cost to developed countries' governments was 5\% of GDP on average (ECB 2015, Millaruelo and del Rio 2017, Blix Grimaldi et al 2016), but the actual experience has varied substantially between countries: in the US, the initial cost of the government support accounted for more than 5\% of GDP while the effective ex-post cost was negative; but in Ireland the expost cost was substantial, 19.6\% of GDP, and in Greece the level of the needed support was "too big to be local," and international support was necessary.

This uncertainty surrounding the Expected Value of Government Support in Financial Crisis occurrence means that for each point on the $\mathrm{X} 1$ axis there is a wide variety of outcomes; moreover, it is obviously non-symmetrical as the probabilities of a major cost are much bigger than the probabilities of a positive outcome. One way of taking this characteristic into account is to assign a greater relative price to this Government Support than to the public debt.

The actual position of the frontier curve will be driven mainly by the explicit and implicit public policies of the government as an insurer of the financial sector. But the size and the degree of globalization of the economy, the pattern of previous financial crises in the country and the historical period under review, will also be determinants of the position of the Capacity Frontier of each country. Under the Classical Gold Standard System for example, this frontier was very close to the origin as the governments in that period were not at all acting as insurer of the financial sector and the level of their public debt was relatively low. But in the period before the recent financial crisis, the frontier was much further away from the origin which corroborates the explicit and implicit "too big to fail" policies and a much higher level of public debt for most industrial countries.

Finally we must recognize that the central bank's actions in any country are key of the actual position of the Government Capacity Frontier as the central bank can buy 
and hold a portion of the public debt. In that scenario, money is created and the public debt is monetized as long as the debt is held by the central bank. In doing so, the central bank not only provides liquidity but also adds to the government's real resources. An increase in the level of debt monetization will move the Capacity Frontier downward to the right, away from the origin, as will be illustrated later. It must be recognized that other central bank actions that create liquidity or money without changing the total amount of government debt held by the central bank are not of this category.

\section{Regulatory Regimes and the Role of the Central Bank}

Graph A exemplifies the long-term relationships between the financial regulation regimes (scope, institutions and products/markets), the size of the financial sector, the level of the public debt and the expected value of the government support to the financial sector in the event of a financial crisis for a given level of central bank monetization.

Let's assume that, for a given time period, the regulator has chosen a point $A$ (a regulatory regime) on the $\mathrm{Y} 1$ axis determining henceforth the scope of the financial sector (point $A$ in Mapping $I$ ) and the set of products/market regulations (point $A$ in Mapping II). We can see that these choices are consistent with an Expected Value of Government Support (point $A_{d}$ on $X 1$ axis) and with a certain size of the financial sector (point A on axis X2) both expressed as a percent of GDP.

As explained earlier, the size of the financial sector, i.e. its assets, corresponds to the debts of the domestic non-financial private sector. Moreover by virtue of the longterm relationship between the private debt (X2) and the public debt (Y2), point $A$ in Mapping II is consistent with point A in Mapping III, that is, a certain size of the public debt also expressed in percent of GDP.

The intersection between the level of public debt (point $A$ on the $Y 2$ axis) and the level of the expected value of government support (point $A$ on the $X 1$ axis) results in point $A_{d}$ in Mapping IV. This point $A_{d}$ is the "demand" for funds expressed by the regulator in order to support the financial sector if a financial crisis arises.

In that case, point $A_{d}$ is well inside the Capacity Frontier and, at this level of debt, the government can offer a larger support as shown by point $A_{s}$. Indeed, this regulatory regime applies in a period where the financial sector is relatively small, the scope of its activities is low, as is the government public debt. The regulator expected level of financial support, $A_{d}$, is therefore much lower than what the government can provide, point $A_{s}$ is on the Capacity Frontier. "The music can continue to play!"

We can think of this case as representative of the period before World War I, when public debts were low and the financial industry small compared to the size of the economy. Moreover, in those days, there were no bank deposit insurance programs and no "too big to fail policies."

It was only after the stock market crash of 1929, the Great Depression and the failures of more than 10,000 banks in the US that Congress adopted, after much 
debate, the Bank Act of June 1933. The Glass-Steagall Act, as it is called, established a new framework of regulatory policies for the US banking system and became a reference for many countries as well. The Glass-Steagall Act created Federal Deposit Insurance and the FDIC; imposed the separation of the commercial and the investment banks; instituted Regulation $Q$, fixing zero interest rates on demand deposit and imposing ceilings on other types of bank deposits; put some restrictions on branch banking and introduced several provisions to limit speculative use of bank credit. Many countries followed suit.

In 1999, the Glass-Steagall Act was officially repealed by Congress, but it had been under attack since the late 1950's and the early 1960's as financial institutions wanted to diversify and expand their business across regulatory boundaries. Moreover, in the 1970's and the 1980's, rising inflation and low-regulated rates on deposits made banks less competitive and less profitable, some of them even began making risky loans in order to pay for the higher cost of borrowing money on the financial markets.

As Markham (2000) put it, the pressure was such that Regulation Q on term deposits was repealed in 1980 and, as time went by, many of the restrictions on branch banking were eliminated while the separation of commercial banks from investment banks became, in fact, less effective. Finally, in 1999, the "universal bank model" was reintroduced in the US. Similar regulatory changes occurred in other countries, especially in the Anglo-Saxon world.

In the words of Graph A, at the beginning of 2000, the scope of the financial system reached a high level on the $\mathrm{Y} 1$ axis, and the global universal bank became the attractive bank model. And despite the fact that since 1986, all domestic regulators have worked to implement Basel I and later Basel II, the "Genie was out of the bottle" and the size of the financial sector increased substantially as a percent of GDP.

Jordà, Schularick and Taylor (2016) recently provided excellent data from 1790 to 2012 showing that, for 17 countries representing more than $50 \%$ of the world GDP, "the median of bank lending to GDP was in the 40-50\% range for most of the preWorld War II period. Private credit collapsed in the great depression and during World War II while public debate expanded rapidly. Bank credit recovered its pre-war level by the 1970s and surged to unprecedented level in the following decades, well over $100 \%$ of GDP." This impressive growth took place at the same time as Basel I and II put more conservative and sophisticated regulations in place to moderate it, but their impacts were offset by the deregulation of the scope of the financial sector over the previous thirty years. Moreover, during that period, the products and markets regulations approach was more focused on well-functioning markets than on unintended consequences of the design of some financial products like CDOs, CLOs, securitization, etc. Product regulations have rarely been viewed as a macro prudential tool.

Using Graph A, it is easy to represent the more recent regulatory regime, i.e. the one prevailing in the early 2000's just before the Great Financial Crisis. Just pick a larger scope of the financial sector at point B in Mapping I on the $\mathrm{Y} 1$ axis; introduce a shift of the regulatory leverage into a more conservative upward direction to take into account the impact of Basel I and II; this point B will still be consistent with a much 
larger Expected Value of Government Support in Case of a Financial Crisis, as the impact of a higher scope of the financial sector (that happened over the previous 30 years) is much more demanding on the Expected Value of Government Support than all the efforts to reduce leverage as required by Base I and II. Similarly in Mapping II, point B corresponds to a much larger financial sector which in turn corresponds to a much higher level of public debt, point B in Mapping III. Now point B in Mapping IV corresponds to a much larger level of Government Support than what the Government can afford to given the Capacity Frontier. Point B is an unstable case ....unless the central bank pushes the Capacity Frontier to the downward right to the needed position by monetizing government debt. Point $B$ then becomes a stable point.

In a financial crisis both central bank actions and government support are all in to "stabilize" the situation. Both of them become insurers.

\section{Conclusion}

\section{From Too big to fail to Too rich to save}

As we look back at financial crises, we realize the high costs they impose on governments. There are obviously the direct costs of the bail-out of failed financial institutions, but there are also the long-term indirect costs of an increase of the public debt ensuing from prolonged and deep recession. But we should not forget the socio-economic costs of the higher and longer unemployment and the ensuing increase in income and wealth inequalities of these financial crises. The biggest cost however may be the loss of trust of the general public toward public institutions, central banks and governments (Trust in the Finance Industry: A GlobeScan Radar eBrief 2016, Dustmann et al 2017), marked, for instance, by the rise of populism both in Europe (Algan et al 2017, Foster and Frieden 2017, Funke, Schularick and Trebesch 2018) and in the US (Sorkin 2018).

While there is debate on the relative importance of cultural and socio-demographic factors in the rise of populism, most studies are convincing about the impact of the last financial crisis on that rise. Foster and Frieden (2017) concluded that: "Crisesdriven economic insecurity is a substantial driver of populism and political distrust."

Henceforth, one cannot assume that the government balance-sheet constraint expressed here as the Capacity Frontier is the only constraint on public policy in time of crises. The recent financial crisis has been very instructive on the limits and constraints of public policies as the crisis grows. Not only do countries with high level of debt lack the capacity to perform macroeconomic and financial stabilization and to resume growth, as documented by Jordà, Schularick and Taylor (2016), but even in an acute financial crisis like that of 2008, the political process under which governments approve any "bail out packages" is complicated, difficult, and sometimes inconclusive. The moral hazard implications of such bail-out packages and the general public loss of trust make these packages even more "unacceptable."

A recent text by Bernanke, Geithner and Paulson (2018) is very relevant on that matter. "In its post-crisis reforms, Congress also took away some of the most 
powerful tools used by FDIC, the FED and the Treasury. Among these changes, the FDIC can no longer issue blanket guarantees of bank debt as it did in the crisis, the Fed's emergency lending powers have been constrained, and the Treasury would not be able to repeat its guarantee of the money market funds. These powers were critical in stopping the 2008 panic."

In other words there exists an implicit "Social Preference Curve" in Mapping IV. The curve is concave as both the public debt and the cost of the government support to the financial sector are "bad goods." The level of the general public utility increases as the curve gets closer to the origin. This Social Preference Curve becomes an effective constraint when the general trust reaches very low levels. This Social Preference Curve is explicitly illustrated in Graph B and we must understand that over the recent past, the curve had moved back towards the origin and that a point like point $B$ would be unacceptable nowadays.

We do not know if and when another financial crisis will come but we can be certain that the next time will be different: "Too Big to Fail" policy has become "Too Rich to Save" policy. If a crisis were to happen, not only would the public debt limit the government's capacity to act as a strong "insurer" in many countries but even in countries where the fiscal capacity was sufficient, the political capacity to act would be an issue and may even prevent any rescue efforts.

\section{The Diabolical Loop}

This schematic view of the Government as regulator and as insurer may be related to the vicious circle between sovereign debt and banks resulting from the capital framework for banks which establishes less strict rules and lower capital requirements for sovereign debts than for other assets on bank balance sheets.

Moreover, government bonds are classified as very liquid and are most of the time used as collateral without any haircuts.

This preferential treatment is the topic of many debates (Lanotte and Tommasino 2018) as it may reinforce the interconnectedness of banks and governments and could be a source of additional instability. In its recent report, the Basel Committee on Banking Supervision has maintained the status quo (Basel Committee on Banking Supervision 2017) but the question remains as it is at the center of the task of completing the European monetary union.

Our framework can be used to illustrate this preferential treatment of government bonds. A change in the regulation that would eliminate this special treatment for government bonds would, everything else being equal, change the position of the Regulatory Leverage curve to a more conservative position and reduce the Expected Value of Financial Support in Case of a Financial Crisis and it would also change the slope of the Financial Support Frontier accordingly (Mapping I).

If the EU were to implement all the recommendations put forward by Agnès Bénassy-Quéré et al (2018) to reconcile risk sharing and market discipline in the euro area, then all the interactions between the scope, the size of the financial 
sector, the public debt as well as the Expected Value of Government Support in case of Financial Crisis would be substantially changed in the euro area. Indeed, the introduction of a sovereign concentration charge of capital and better designed deposit insurance program would both reduce the Regulatory Leverage while introducing a rule base long-term program of debt reduction. Creating a European stabilization fund would weaken the long-term relationships between the private debt and the public debt (public debt DNA). This set of recommendations is the perfect example of the importance of looking at financial regulation with a comprehensive approach addressing at the same time the regulations that directly impact the balance sheets of institutions as well as those impacting the scope, the products and the markets. 


\section{Graph A: Government as regulator and insurer}

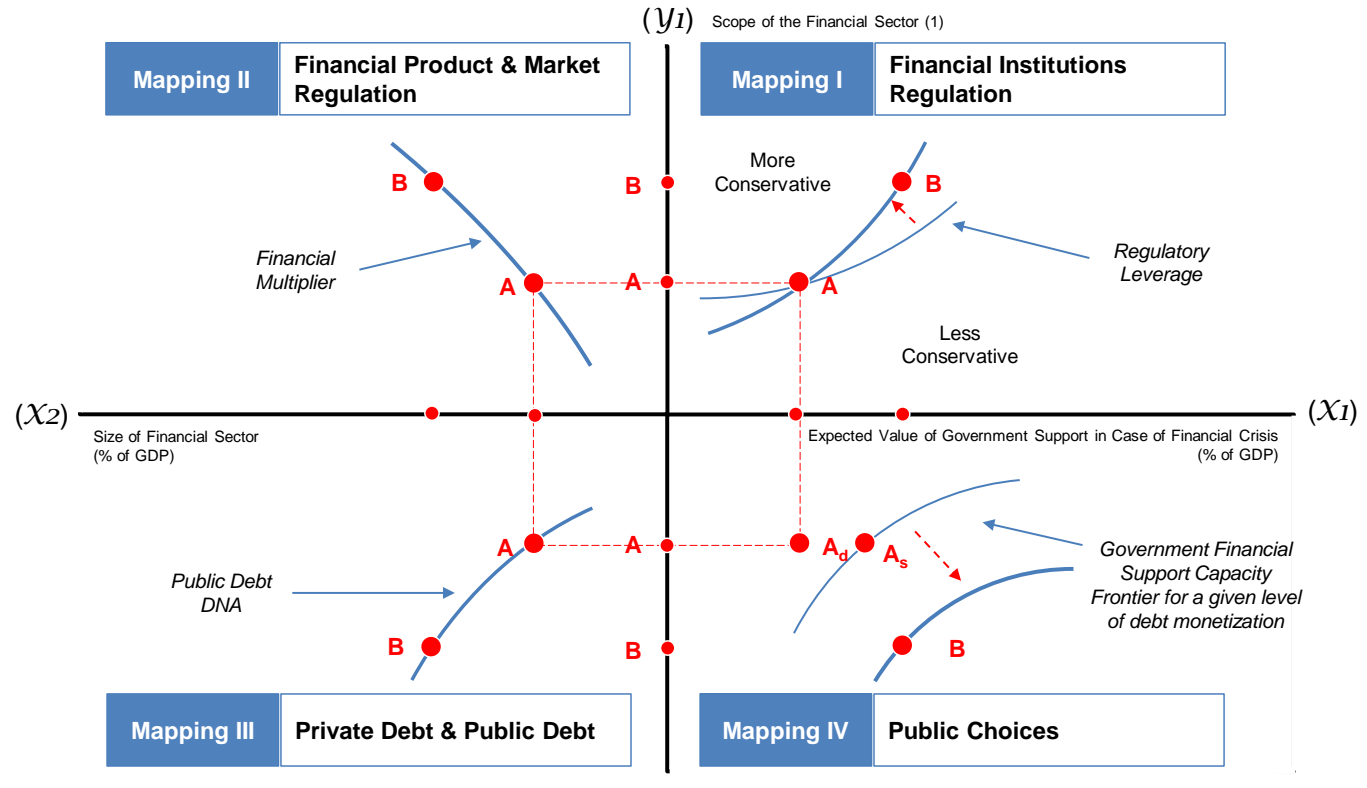

$\left(y_{2}\right)_{\substack{\text { Government } \\(\% \text { of GDP })}}^{\text {Debt }}$

(1) Measured by the total of banks' wholesale fundings, the banks' foreign assets and the banks' off-balance sheet assets as $\%$ of total assets in the sector

\section{Graph B: Social Preference Curve}

$\left(\chi_{1}\right)$

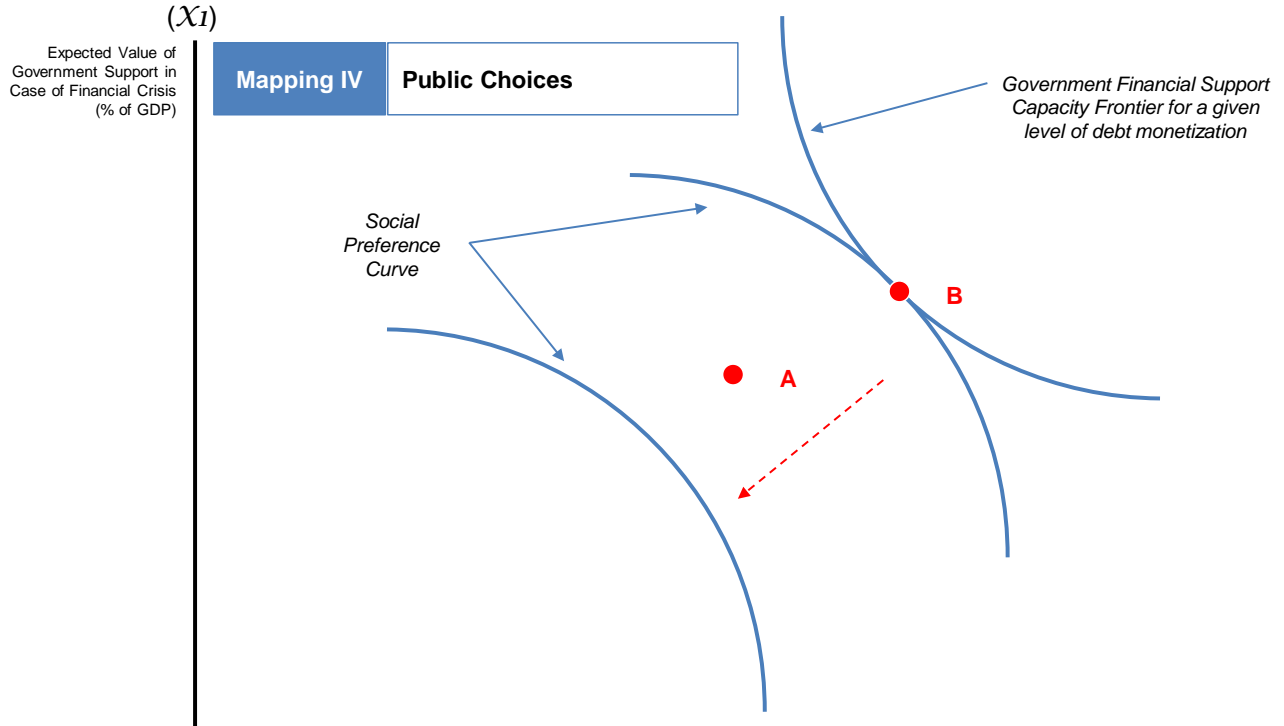




\section{REFERENCES}

Alessandri, Piergiorgio and Andrew G. Haldane (2009). "Banking on the State." Bank of England. http://citeseerx.ist.psu.edu/viewdoc/similar?doi=10.1.1.178.9620\&type=ab

Algan, Yann, Sergei Guriev, Elias Papaioannou, and Evgenia Passari.(2017). "The European Trust Crisis and the Rise of Populism." Brookings Papers on Economic Activity, BPEA Conference Drafts, September 7-8, 2017. https://www.brookings.edu/wp-content/uploads/2017/09/4 alganetal.pdf

Allen, Franklin, Elena Carletti, Itay Goldstein, Agnese Leonello (2015, March). "Moral Hazard and Government Guarantees in the Banking Industry." Journal of Financial Regulation, 1(1): 30-50, https://doi.org/10.1093/jfr/fju003

Antill, Samuel, David Hou and Asani Sarkar (2014, March). "Components of U.S. Financial Sector Growth, 1950-2013." Federal Reserve Bank of New York Economic Policy Review. 20(2).

Basel Committee on Banking Supervision (2017). "The regulatory treatment of sovereign exposures." BIS. Discussion paper

Bénassy-Quéré, Agnès et al (2018, January). "Reconciling risk sharing with market discipline: A constructive approach to euro area reform." Centre for Economic Policy Research. Policy Insight No. 91.

Bernanke, Ben S., Timothy F. Geithner and Henry M. Paulson Jr. (2018, September 7). "What We Need to Fight the Next Financial Crisis." [Opinion]. The New York Times, Web

Blix Grimaldi, Marianna, et al. (2016). "Estimating the size and incidence of bank resolution costs for selected banks in OECD countries." OECD Journal: Financial Market Trends, published online first. DOI: http://dx.doi.org/10.1787/fmt-2016-5j|vbslktw7j

Brunnermeier, Markus K., Luis Garicano, Philip R. Lane, Marco Pagano, Ricardo Reis, Tano Santos, David Thesmar, Stijn Van Nieuwerburgh, and Dimitri Vayanos (2016). "Breaking the Sovereign-Bank Diabolic Loop: A Case for ESBies." American Economic Review, Papers and Proceedings (May), 1-11.

Deghi, Andrea, Peter Weiz and Dawid Zochowski (2018, May). "A new financial stability risk index to predict the near-term risk of recession." Financial Stability Review, European Central Bank, vol. 1.

Dustmann, Christian, Barry Eichengreen, Sebastian Otten, André Sapir, Guido Tabellini, and Gylfi Zoega (2017). "Europe's Trust Deficit: Causes and Remedies." Monitoring International Integration 1. Centre for Economic Policy Research.

Ersel, Hasan (2011). "Basel I and Basel II: History of an Evolution." HSE Lecture III. PowerPoint presentation.

European Central Bank (2015). "The Fiscal impact of financial sector support during the crisis." ECB Economic Bulletin 6: 74-87.

Financial Stability Board, Global Shadow Banking Monitoring Report 2017 (Basel: FSB, 5 March 2018) 
Foster, Chase and Jeffry Frieden (2017, December). "Crisis of Trust: Socio-economic determinants of Europeans' confidence in government." European Union Politics. 18(4): 511-535. Publisher's version.

Funke, Manuel, Moritz Schularick, and Christoph Trebesch (2018, September 13). "The Financial Crisis is Still Empowering Far-Right Populists." Foreign Affairs. Snapshot web edition.

Gertler, Mark and Simon Gilchrist, 2018. "What Happened: Financial Factors in the Great Recession." Journal of Economic Perspectives, 32(3): 3-30.

GFMA, "Global Regulatory Reform Proposals, Side-by-side Comparisons and Timelines." As of 31 March 2013 http://www.gfma.org/uploadedFiles/GFMA-Matrix-Global-RegulatoryReform-Proposals.pdf

International Monetary Fund, Fiscal Monitor-Now Is the Time: Fiscal Policies for Sustainable Growth (Washington, April 2015).

Jordà, Òscar, Moritz Schularick and Alan M. Taylor (2013). "When Credit Bites Back." Journal of Money, Credit and Banking 45(s2): 3-28 https://doi.org/10.1111/imcb.12069

Jordà, Òscar, Moritz Schularick and Alan M. Taylor (2016, February). "Sovereigns Versus Banks: Credit, Crises, And Consequences." Journal of the European Economic Association, European Economic Association, 14(1): 45-79.

Laeven, Luc and Fabián Valencia (2013). "Systemic Banking Crises Database." IMF Economic Review 61(2): 225-270.

Lanotte, Michele, Pietro Tommasino (2018, February 5). "Recent developments in the regulatory treatment of sovereign exposures." VoxEU.

Markham, Jerry W. (2000). "Banking Regulation: Its History and Future." 4 N.C. Banking Institute 221. http://scholarship.law.unc.edu/ncbi/vol4/iss1/10

Millaruelo, Antonio and Ana del Río (2017). "The cost of interventions in the financial sector since 2008 in the EU countries." Analytical Articles, April, Banco de España

Santos, João A.C. (2000). "Bank Capital Regulation in Contemporary Banking Theory: A Review of the Literature." BIS Working Paper No. 90.

Schularick, Moritz (2012). "Public debt and financial crises in the twentieth century." European Review of History: Revue européenne d'histoire, 19(6): 881-897. https://doi.org/10.1080/13507486.2012.739149

Schularick, Moritz and Alan M. Taylor (2012). "Credit Booms Gone Bust: Monetary Policy, Leverage Cycles, and Financial Crises, 1870-2008." American Economic Review 102(2): 1029-61.

Sorkin, Andrew Ross (2018, September 10). "From Trump to Trade, the Financial Crisis Still Resonates 10 Years Later." DealBook - The New York Times Web.

Stolz, Stéphanie Marie and Michael Wedow (2011). "Government Measures in Support of the Financial Sector in the EU and the United States." Intereconomics: Review of European Economic Policy, 46(1): 53-60. 
Trust in the Finance Industry: A GlobeScan Radar eBrief (2016). https://globescan.com/wpcontent/uploads/2017/11/GlobeScan Radar 2016-Finance eBrief.pdf 